\title{
AN IMPROVED DESIGN AND CONSTRUCTION WITH PERFORMANCE EVALUATION OF A MELON SEEDS SHELLER WITH A CONTINUOUS SEPARATOR
}

\author{
Adeleke M.B ${ }^{1}$

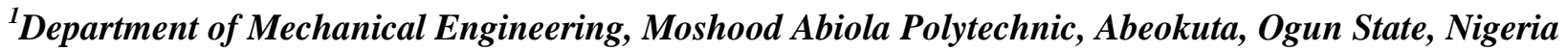

\author{
Orelaja O.A $\mathbf{A}^{*}$ \\ ${ }^{2}$ Department of Mechanical Engineering, Moshood Abiola Polytechnic, Abeokuta, Ogun State, Nigeria \\ * Corresponding Author: (Orelaja O.A)
}

Article DOI: https://doi.org/10.36713/epra5771

\begin{abstract}
An improved designed and constructed melon seed sheller with continuous separator comprises of electric motors, hopper, shelling, and separator units for separating melon seed from its shell, was developed. This machine which was fabricated using locally sourced standard materials by eliminating the drudgery involved in the melon kernel separation. As we know that melon seed is a vital oil seed that is mostly used in food industries. Shelling of this crop is a problem due to the stress and time that is involved, prior to its usage. In order to address these challenges associated with shelling and separating the melon from its kernel, an improved design of melon shelling machine of melon seeds for both commercial and a small scale was presented and evaluated in this research work. Parameters evaluated include shelling efficiency, percentage seed shelled, and output volume with time and general machine capacity. The machine was constructed using locally available materials and consists of a hopper, frame, shelling and cleaning unit, chutes and prime mover. Shelling speeds of the machine and seed moisture content of melon affects the rate, efficiency and percentage seed damage. Adopting this design concept is recommended because it minimizes seed breakage during manual shelling, it also enhanced hygiene as human direct contact with the seed during shelling is reduced.
\end{abstract}

KEY WORDS: Improved design, melon seed, melon kernel, performance evaluation, efficiency.

\subsection{INTRODUCTION}

Melon having a botanical name (Citrullus lanatus ssp coloeynthoides), it bears its fruits in pods with thousands of seeds embedded in this pod. The harvested process of melon pods are classified to three major edible products, (i) melon kernel, (ii) melon flour and (iii) melon oil. The processing stages are the field and factory/house operations. Melon seeds are extracted from its pod after harvest in farm/field. The field process involves depodding of the fruit from the hub to expose its internal content for proper fermentation and separation of the seeds from the fermented pulp by washing/sieving and drying of the seeds. Dehusking (shelling) of external shell of the melon seed from its cotyledon/kernel, separation of its shell and kernel is a continuous factory operations system according to [1-2]. This operation can be carried out in the field or at the storage environment [3]. Melon is mostly called,, Egusi" by Yorubas, Agusi" by Hausas and,, Ogil" by Igbo people of Nigeria [4]. The main types of melon found in Nigeria 


\section{SJIF Impact Factor: 7.001| ISI I.F.Value:1.241| Journal DOI: 10.36713/epra2016 ISSN: 2455-7838(Online) EPRA International Journal of Research and Development (IJRD)}

are Bara, Serewe, Sofin, variety "E" and "N" types [5]. According to [6] the melon seed can be grounded into thick paste for making soup or stew as well as serving as a raw material in the production of margarine, salad, "robo cake", baby food, livestock feeds, local pomade, soap and its shells can be used as poultry litter. Despite the large productivity and nutritional potentials of this crop, there has been a hindrance to the use of melon for large scale production of oil and protein sources. This is as a result of inability to shell melon to meet the capacity required for industrial purposes. The seed called Shelling of melon as a unit operation is therefore an important step towards the processing of melon to its finished products. Most farmers, who cultivate this crop both in Nigeria and West Africa alike, encounter several processing challenges of shelling this crop, as it requires a relatively high expenditure and human manual shelling energy which is a major concern. The inability to effectively shell melon in order to meet the requisite volume necessary for industrial utilization, has been a hindrance to its use for large scale production of various commodities [5][7]. It is our belief that the conventional or manual method of shelling melon is not good enough and cannot meet up with the demand, due to inefficient, tedious and time consuming, thus limiting the availability of their products in the market [4][8]. However, researches have shown that melon is an excellent source of protein with higher levels of amino acids than soybean meal. It is also used as an ingredient for making soup/stew, melon bread/cake, etc when processed into flour while its oil is medicinal constituting a raw material for production of pomade, soap, margarine etc. The two by-products of the factory stage of melon processing- the shell and residual chaff are also of economic value. The chaff is a source of protein for livestock feed and also for producing a local melon snack known as "ROBO" while the shell is an excellent poultry litter is also used for reclaiming crude oil polluted soil [5][9].

There are several breakthrough recorded in the design and development of mechanized systems for factory melon processing operations such as melon shellers, burr mills, blenders and melon seed oil expeller of various sizes are acknowledged [5][9][10][11][12] However, high melon seed/kernel breakage inefficacy constitutes the major consistent limitation of melon seed shellers. According to [11], he developed an integrated melon shelling and cleaning machine,but the efficiency is lower than what is expected. An Improved Design and Construction of a Melon seeds sheller with a continuous separator for processing melon is highly required to meet the people's demand with tremendous volume within a short time. This is because freshly shelled melon tastes has a better than those that have been dehusked for a longer period of time. Melon kernel easily absorbs moisture and consequently ferments at a high rate than the undehusked seed as stated by [13]. According to [14], he said crushed melon kernels are easily susceptible to deterioration which affects the taste consequently. High volume of melon seed/kernel breakage associated with the existing melon shellers is due to the inability to control the speed of the shelling machine with respect to the various melon species (bara, serewe, sofin etc). Also, apart from the high set up cost of using individual stand-alone shelling, separation milling, discharging and reloading of processing materials amongst these machines are seen in the existing melon seed processing technologies which are stressful and unhygienic for human to consume. In order to reduce the set up cost, drudgery, losses due to melon kernel breakage as well as improve hygiene in melon seed processing, an improved design and construction of a melon seeds sheller with a continuous separator was developed to save time in the production sector.

In addition, with the prevalence of the erratic power supply, which is synonymous with Nigeria, it is important to look for other means of powering equipment, we therefore, employed fuel-powered sheller which is a better choice and has advantages over the electrical powered one due to non-reliance on electricity. Different scholars have worked on the design and development of shellers [15][16][17]. But not much work has been done in the literatures on the design and construction of a mechanized fuel-powered melon sheller with a continuous separator. Therefore, there is a need for a more cost effective, simple, friendly, hygienic and technologically feasible system for shelling melon. However, the main objectives of this experimental work are to produce an improved design and construct a fuel powered melon sheller with a continuous separator and to evaluate the performance of this machine.

\subsection{MATERIALS AND METHODOLOGY}

\subsection{Materials}

The materials used for the construction of this improved design and construction of a melon seeds sheller and continuous separator include: mild steel, ball bearings, angle iron, static disc, electrode, single and double groove pulley, shaft and belt. The part drawing of the melon sheller showing all the internal component of the machine is as shown in Figure 1. 


\section{EPRA International Journal of Research and Development (IJRD)}

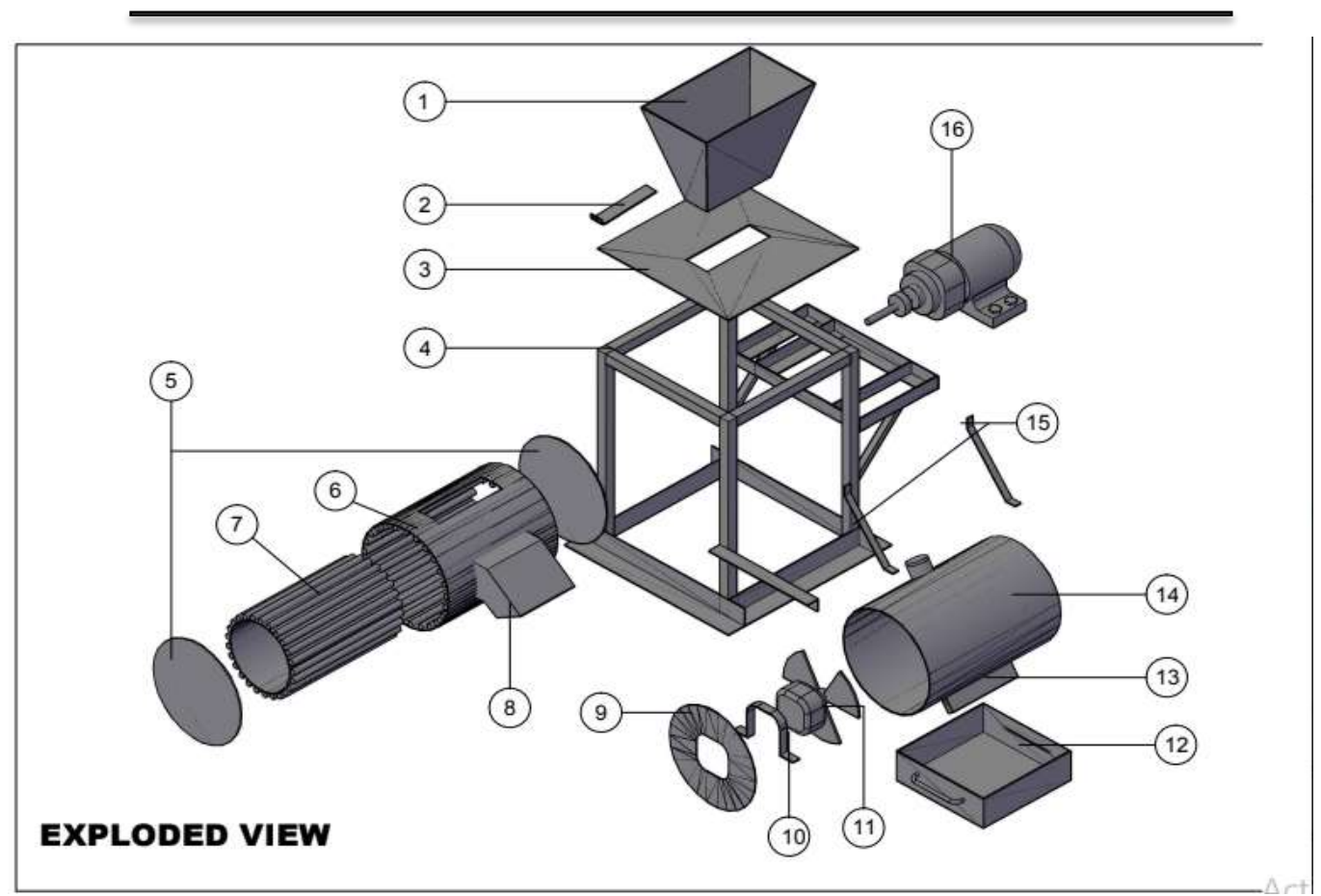

Figure 1 Sketch and line diagram of the melon sheller : 1 - Hopper; 2 - sight glass; Pulley; 3 - Frame cover; 4 -Housing frame; 5 - Disc cover; 6- Sheller ; 7- Sheller; 8- Outlet for shelled melon for melon; 9- Blower guide;

10- Guide; 11-Fan; 12- Outlet plate; 13- Blower outlet; 14-Blower; 15- Hub support; 16- Electric mower .

\subsection{Construction and description of the machine}

The Auto-Cad shaded view showing all the views of the constructed melon sheller was shown in Figure 2. Locally available, but quality materials (mild steel, angle iron, pulleys, shaft, belts and motor) which produce the desired objective at minimum cost were used. The machine consists of the hopper, shelling unit (which consists of rotating disc and static disc), the frame, the cleaning unit and chutes. To improve the free flow of seeds into the shelling unit, the conical shaped hopper was fabricated using mild steel into a height of $220 \mathrm{~mm}$, upper radius of $250 \mathrm{~mm}$ and lower radius of $80 \mathrm{~mm}$ and inclined at an angle of $115^{\circ}$. The shelling unit consists of the rotating and static discs, vanes and the shelling drum. The outer part of the rotating disc is lined with flat metal blades ( $3 / 4$ inch) of $50 \mathrm{~mm}$ length were welded at an angle of $75^{\circ}$, and were arranged side by side with a distance of $9 \mathrm{~mm}$ between the blades, along the diameter $(180 \mathrm{~mm})$ of the disc, forming vane slots at the edges of the rotating disc. The static disc consists of flat metal rods of 150 $\mathrm{mm}$ length, arranged side by side and welded at a distance of $10 \mathrm{~mm}$ to each other at an angle of $60^{0}$ along the walls of the fixed drum which formed spikes. The frame which is the support on which the whole unit rests, was made from angle iron into a rectangular of size $1120 \mathrm{~mm} \times 300 \mathrm{~mm} \times 750 \mathrm{~mm}$ high. 

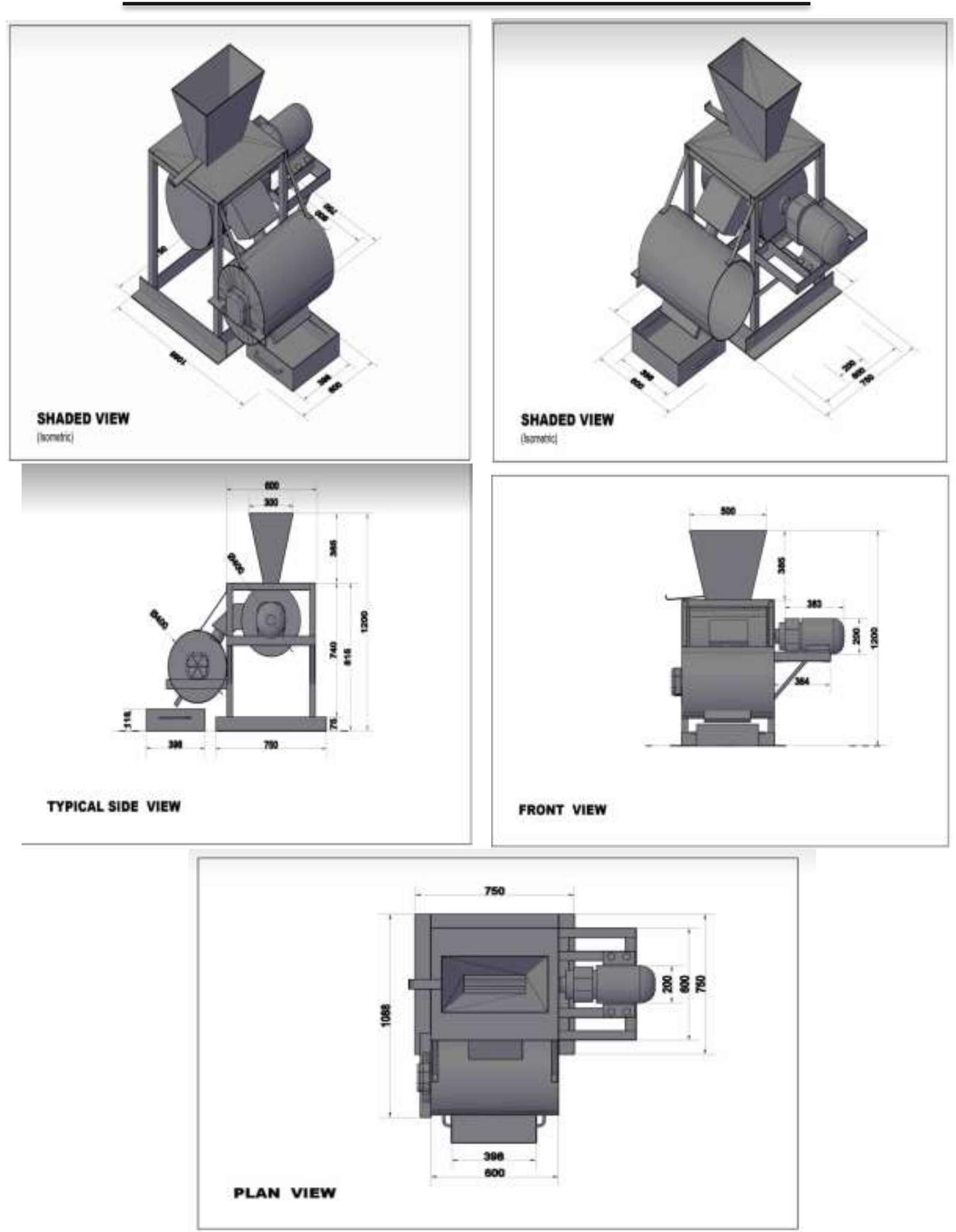

Figure 2 Showing the Auto-Cad shaded view of the constructed melon sheller

(c) 2020 EPRA IJRD | Journal DOI: https://doi.org/10.36713/epra2016 | www.eprajournals.com |394 | 


\section{EPRA International Journal of Research and Development (IJRD)

\subsection{Design considerations}

This machine was designed after a detailed experimental analysis of the results obtained from the previously made melon shelling machines, the lapses and their inefficiency was observed and noted so as to ensure that our design and construction was based on an improved design. A machine design should not be only technically good and have a precise operating system, but it should be capable of performing the purpose of the proposed application. It is however expedient that a melon sheller apart from effectively performing its proposed application, it should also satisfy design and process requirement throughout its service life and must be durable and hygiene. The following factors were also considered in the design of the melon seed sheller: (i) availability of raw materials for construction; (ii) mechanical properties of the material; (iii) cost (iv) power requirement; (iv) ease of fabrication, assembling and dismantling. The pictorial view of the assembled machine is shown in figure 3.

\subsection{Design computations}

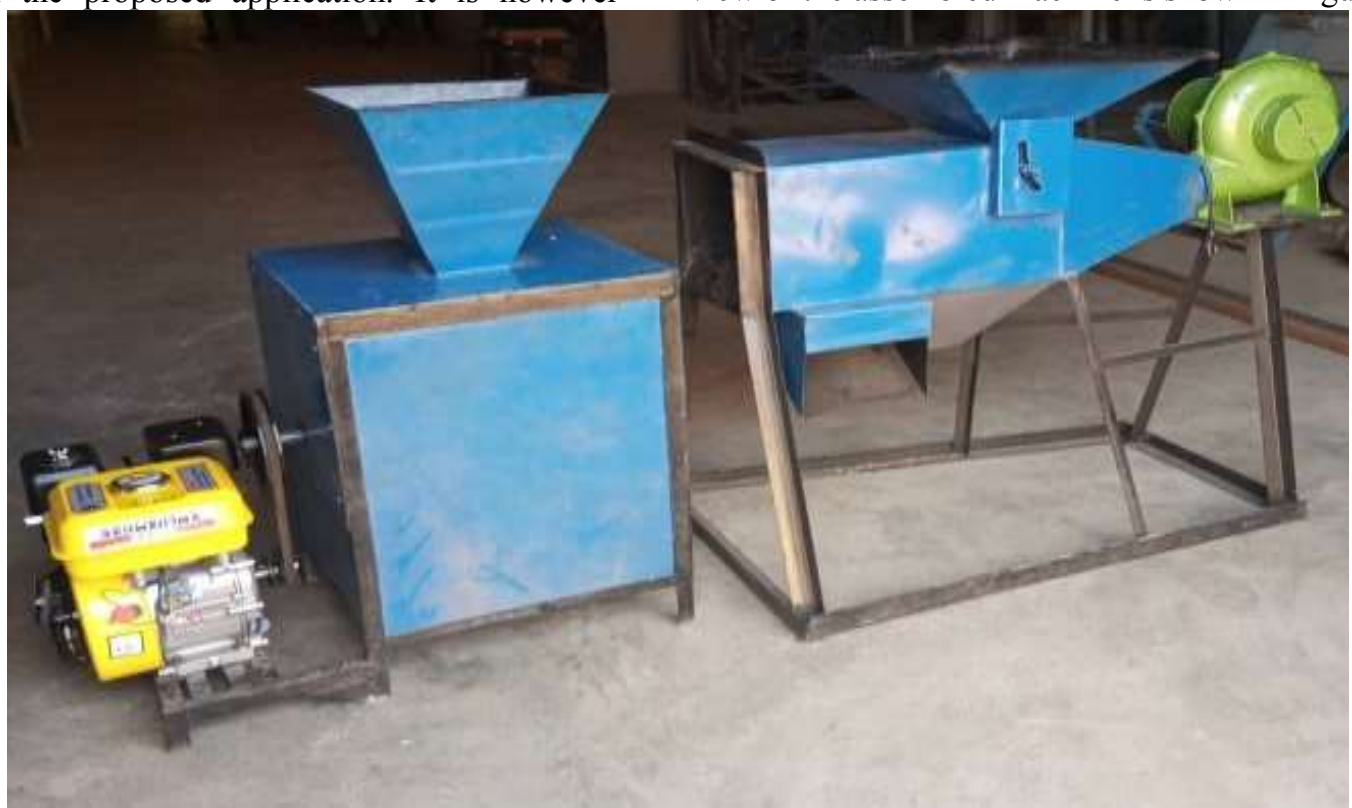

Figure 3 Showing the pictorial view of the assembled melon shelling machine

The significant properties of melon seed influenced the basic design of this machine. Basic considerations were given to the design for the capacity and size of the machine, power requirement, speed of the pulley, length of the belt, diameter of the shaft.

\section{A. Power Transmission Requirement for Shelling}

The total power required for shelling was calculated using the equation as stated by [20] and as cited by [21].

$P_{t}=P_{\text {inner drum }}+P_{\text {shaft }}+P_{\text {shelling }}$

$P_{\text {shelling }}$ is negligible since seeds are not resident in sheller but flow through in pieces.

Therefore, $P_{T}=P_{\text {inner drum }}+P_{\text {shaft }}$

But the shaft and inner drum are welded together,

So, $P_{T}=P_{\text {inner } \text { drum }}$

with shaft,

$P_{\text {inner drum }}$ with shaft $=T_{\text {inner }}$ drum with shaft $\mathrm{X} V_{\text {inner }}$ drum with shaft,

$V_{\text {inner drum }}$ with shaft $=\frac{2 \pi \mathrm{N}}{60} \mathrm{~m} / \mathrm{s}$

$T_{\text {inner drum }}$ with shaft is the torque $(\mathrm{Nm}) \mathrm{N}=$ is the number of revolution per minute of the inner drum with shaft $=400 \mathrm{rpm}$

$T_{\text {inner } \text { drum }}$ with shaft $=$ mass $\mathrm{x}$ acceleration due to gravity $\mathrm{x}$ radial distance

But Mass inner drum with shaft $=5 \mathrm{~kg}$, 


\section{EPRA International Journal of Research and Development (IJRD)}

Acceleration due to gravity $=10 \mathrm{~m} / \mathrm{s}^{2}$

Radial distance $=0.15 \mathrm{~m}$

$T_{\text {inner drum }}$ with shaft $=5 \times 10 \times 0.15=7.5 \mathrm{Nm}$

$P_{\text {inner } \text { drum }}$ with shaft $=7.5 \times \frac{3.142 \times 400}{60 \times 1000}=0.3142 \mathrm{KW}=0.4214 \mathrm{Hp}$

Using a power factor of 1.5 , power required is $0.6321 \mathrm{Hp}$, therefore an electric motor of $1 \mathrm{Hp}$ is selected to power the inner drum with shaft and shell the seeds.

\section{B. Analysis of Driven And Driving Pulley \\ Let: \\ $N_{1}=$ Revolution per minutes of driving pulley \\ $N_{2}=$ Revolution per minutes of driven pulley \\ $D_{1}=$ Diameter of driving pulley \\ $D_{2}=$ Diameter of driven pulley \\ $V_{1}=$ Speed in $(\mathrm{m} / \mathrm{s})$ of driving pulley \\ $V_{2}=$ Speed in $(\mathrm{m} / \mathrm{s})$ of driven pulley \\ The diameter of driven pulley selected, \\ $\mathrm{D}_{2}=45 \mathrm{~mm}$}

The ratio of the driven pulley outer diameter to that of the driving pulley outer diameter is rated as 3.5:1

From the equation (7); $N_{1} D_{1}=N_{2} D_{2}$ i.e $\mathrm{N} 1 / \mathrm{N} 2=3.5 / 1$

Therefore $\mathrm{N}_{1}=3.5 \mathrm{~N}_{2}$

But $\mathrm{N}_{1}=1400 \mathrm{rpm}$ as seen on $1 \mathrm{Hp}$ electric motor

$\mathrm{N}_{2}=\mathrm{N} 1 / 3.5=1400 / 3.5=400 \mathrm{rpm}$

Again from the equation (9);

$N_{1} D_{1}=N_{2} D_{2}$

$D_{2}=N_{1} D_{1} / N_{2}=1400 \times 45 / 400=157.5 \mathrm{~mm}$

\section{To Obtain Speed of Driving and Driven Pulley}

$V_{1}=\pi N 1 D 1 / 60=3.142 \times 1400 \times 45 / 60=3299.1 \mathrm{~mm} / \mathrm{s}=3.299 \mathrm{~m} / \mathrm{s}$

$V_{2}=\pi \mathrm{N} 2 \mathrm{D} 2 / 60=3.142 \times 400 \times 157.5 / 60=3299.1 \mathrm{~mm} / \mathrm{s}=3.299 \mathrm{~m} / \mathrm{s}$

Which implies that there s no belt slip since $V_{1}=V_{2}=3.299 \mathrm{~m} / \mathrm{s}$

The angle of lap $(\Theta)$ of each of the drives was computed as $180^{\circ}$ (3.14rad), using Equation (13) while the belts' speed for the electric motor/speed reducer and speed reducer conveyor drives were determined as $9.42 \mathrm{~m} / \mathrm{s}$ and $0.16 \mathrm{~m} / \mathrm{s}$ respectively using Equation (14)

$\Theta=180-\left[2 \sin ^{-1}\left(D_{2}-D_{1}\right) / 2 C\right.$

$\mathrm{V}=\pi \frac{N_{2 D_{2}}}{60}$

Tensions on the tight side, /slack side of the belts for electric motor/speed reducer and speed reducer/paddle drives were determined as $160.52 \mathrm{~N} / 8.85 \mathrm{~N}$ and $170.10 \mathrm{~N} / 9.37 \mathrm{~N}$ respectively from equation 15$)$, (16) (17) and (18).

$T_{j}=T_{\text {max }}-T_{c}$

$\tau_{\text {max }}=\sigma \alpha$

$\tau_{c}=\mathrm{m} v^{2}$

$2.3 \log \tau_{i} / \tau_{j}=\mathrm{T} \theta \operatorname{cosec} \beta$

Where $T_{\max }$ and $T_{c}$ are the respective maximum and centrifugal tension of the belts while the groove angle, $\beta$, coefficient of friction between the pulleys and the belts, $\mu$, maximum safe stress, $\sigma$, mass per unit length, $\mathrm{m}$ and the cross sectional area, a, of the belts were obtained from IS: $2494-1974$ standard [22] as $0.3,19 \mathrm{o}, 2.1 \mathrm{~N} / \mathrm{mm} 2$, $0.108 \mathrm{~kg} / \mathrm{m}$ and $81 \mathrm{~mm} 2$ respectively. The result of this analysis indicated $6.26 \mathrm{~mm}, 17.4377 \mathrm{~mm}$, and $15.811 \mathrm{~mm}$ as the minimum diameters required of shelling drum, auger and paddle conveyor shafts respectively thus, standard 


\section{EPRA International Journal of Research and Development (IJRD) \\ Volume: 5 | Issue: 11 | November 2020 \\ - Peer Reviewed Journal}

$6.5 \mathrm{~mm}, 18 \mathrm{~mm}, 16 \mathrm{~mm}$ and diameter shafts were consequently selected for the respective shaft. The Figure 4 and Figure 5 below shows the force analysis of the shelling unit and the main driving shaft.

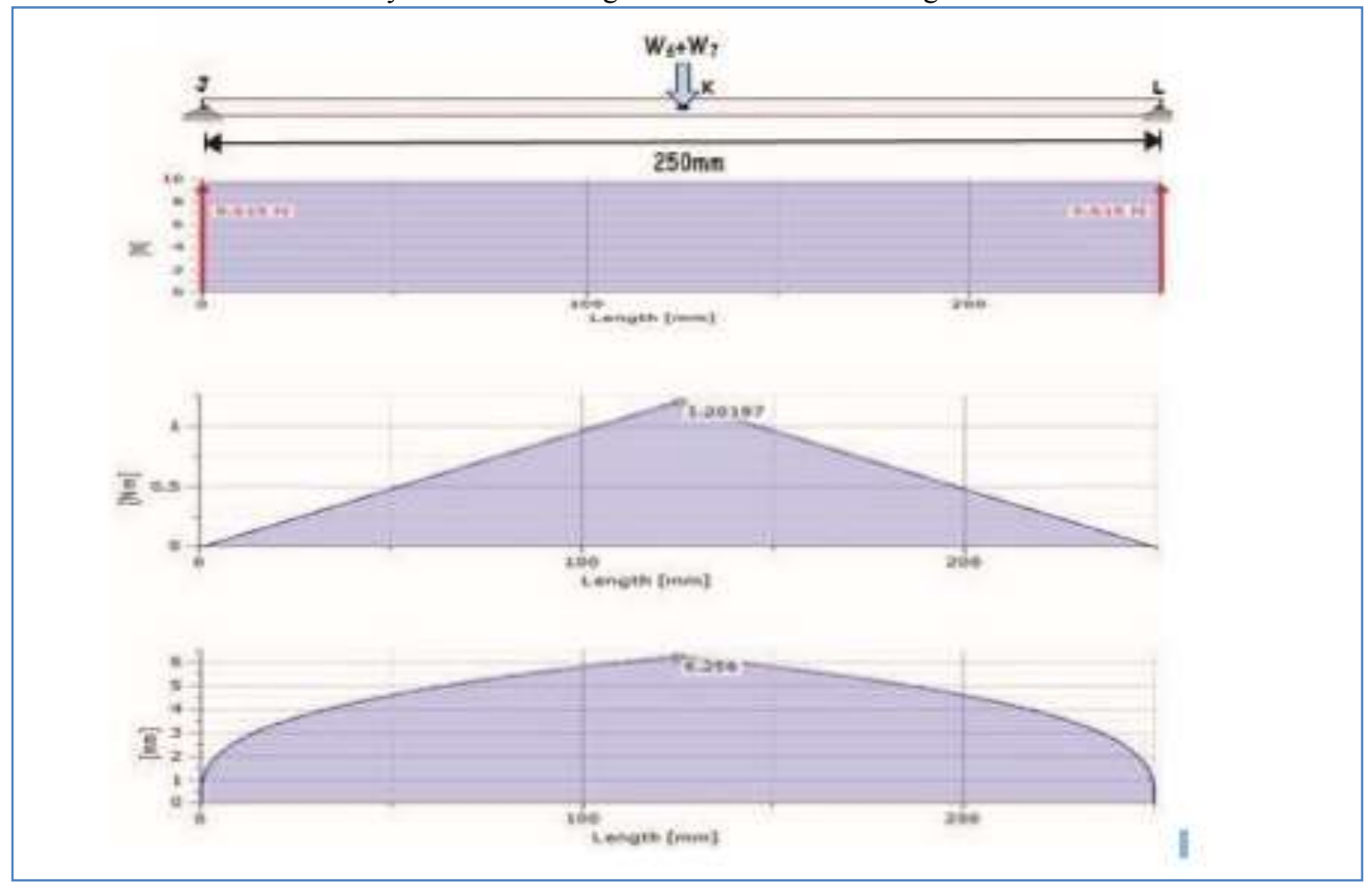

Figure 4 Force Analysis of the Shelling Unit

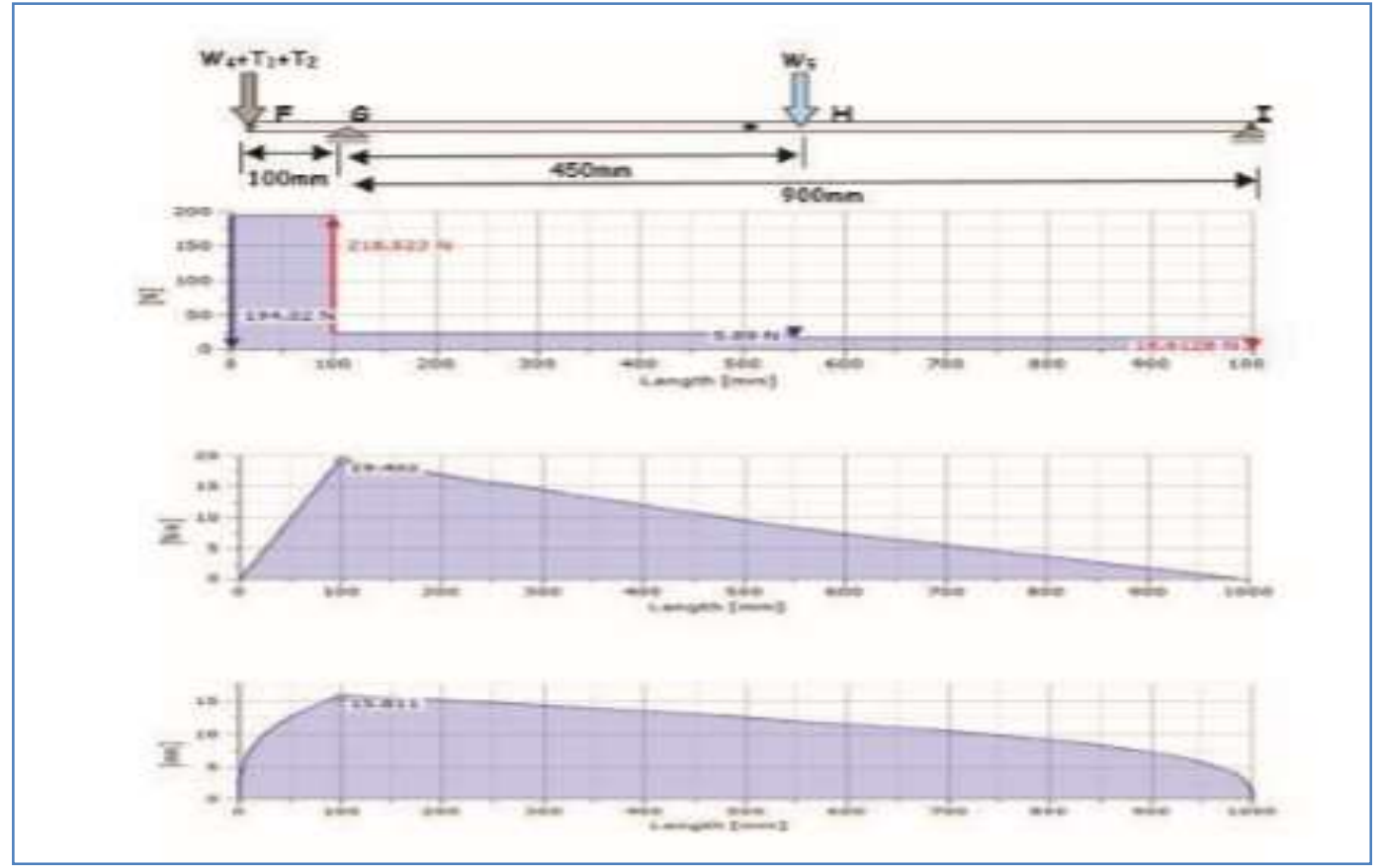

Figure 5. Force Analysis of the Main Driving Shaft 


\section{SJIF Impact Factor: 7.001| ISI I.F.Value:1.241| Journal DOI: 10.36713/epra2016 IISSN: 2455-7838(Online) EPRA International Journal of Research and Development (IJRD)}

\section{Analysis of the Weight Capacities of the Shelling Unit}

The volume capacity of the shelling unit, depends on the volume of the hopper; that of the separation chamber depends on the volume of the U-trough as well as the volume occupied by the paddle shaft/paddles integrated assembly while that of the press depends on the volume of the press barrel, auger membrane, helix and cone. The weight capacities were thus derived from the weight-density-volume relationship.

$$
\mathrm{W}=\rho \mathrm{vg}
$$

Where $\rho=$ density, $\mathrm{v}=$ volume and $\mathrm{g}=$ acceleration due to gravity $\left(9.8 \mathrm{~m} / \mathrm{s}^{2}\right)$.

Considering $94 \%$ head space for the separation chamber and $25 \%$ head space for the shelling unit, the effective weight capacities of the shelling unit and separation chamber, were determined as $5.89 \mathrm{~N}$ and 5.89 from Equation (2), (3), (4) and (5) respectively.

$$
\begin{aligned}
& W_{1}=2.45 \mathrm{H} \rho_{m}\left(L_{\tau} W_{\tau}+L_{b} W_{b}+\sqrt{L_{\tau} W_{\tau} L_{b} W_{b}}\right) \\
& W_{3}=7.36 \rho_{m}\left(1 / 2 \pi r_{3}^{2} l_{3}-\left[\pi r_{P}^{2} l_{P}+n\left(l_{f} b_{f} h_{f}+l_{1} b_{1} h_{1}\right]\right)\right. \\
& W_{3}=7.36 \rho_{k}\left(\pi r_{c}^{2} l_{c}-\left[\pi r_{a}^{2} l_{a}+2 \pi^{2} r_{h}^{2} \sqrt{R^{2}+\left(\frac{Z}{N}\right)^{2}+\frac{1}{3}} \pi\left(r_{b}^{2} h_{b}-r_{t}^{2} h_{t}\right)\right]\right.
\end{aligned}
$$

Where and are the respective bulk densities of unshelled melon and melon cotyledon at moisture content between 9.53-24.08\% (R Abu et al, 2007); $\mathrm{L}_{\mathrm{t}}(0.3 \mathrm{~m}), \mathrm{L}_{\mathrm{b}}(0.1 \mathrm{~m}), \mathrm{L}_{\mathrm{a}}(0.8 \mathrm{~m}), \mathrm{L}_{\mathrm{p}}(0.8 \mathrm{~m}), \mathrm{l}_{\mathrm{a}}(0.04 \mathrm{~m}), \mathrm{l}_{\mathrm{f}}(0.04 \mathrm{~m}), \mathrm{l}_{\mathrm{l}}(0.4 \mathrm{~m})$ and $l_{a}(0.4 \mathrm{~m})$ constitute the respective lengths of the top aperture of the hopper, base aperture of the hopper, separation trough, paddle shaft membrane, leather pad, flat bar, casing and auger membrane; $W_{\tau}(0.3 \mathrm{~m}), W_{b}(0.08 \mathrm{~m}), b_{1}$ $(0.005 \mathrm{~m})$ and $\mathrm{b}_{\mathrm{f}}(0.003 \mathrm{~m})$ are the respective widths of the hopper's top aperture, hopper's base aperture, flat bar and leather pads; $r_{a}(0.125 \mathrm{~m}), r_{b}(0.0085 \mathrm{~m}), r_{a}(0.014 \mathrm{~m}), r_{c}(0.0425 \mathrm{~m}), r_{h}(0.005 \mathrm{~m}), \mathrm{R}(0.045 \mathrm{~m}), r_{b}(0.0425 \mathrm{~m})$, and $r_{\tau}$ $(0.02 \mathrm{~m})$ are the radius of the separation trough, paddle shaft membrane, auger membrane, barrel, rod used in forming the helix, helix, base of the cone frustum and top of the cone frustum respectively; $h_{f}(0.03 \mathrm{~m}), \mathrm{H}(0.15 \mathrm{~m})$, $h_{1}(0.03 \mathrm{~m}), \mathrm{Z}(0.09 \mathrm{~m}), h_{b}(0.08 \mathrm{~m})$ and $h_{\tau}=0.01 \mathrm{~m}$ are the respective heights of the leather pad, hopper, flat bar, helix, complete cone and cone frustum while the number of paddles, $\mathrm{n}$ and revolutions of helix formed, $\mathrm{N}$ are 24 and 5 respectively.

\subsection{Selection of Electric Motor}

The power, required for the operation of the shelling unit was determined as $815.74 \mathrm{~W}$ (1.09 HP) using equations (15),(16), (17),(18),(19),(20) and( 21) by (Khurmi and Gupta,2005).

$P_{1}=T_{\omega}$

$T=I \alpha$

$\alpha=\omega^{2} r$

$\mathrm{I}=m r^{2}$

The mass of the shelling drum, $\mathrm{m}$; radius of the shelling drum from the axis of rotation, $r$ and design speed of cylindrical drum, $\omega$ are $1.35 \mathrm{~kg}, 85 \mathrm{~mm}$ and $99.48 \mathrm{rad} / \mathrm{s}(950 \mathrm{rpm})$ respectively. This is represented by equation (27) as stated by Khurmi and Gupta, (2005),

$P=\left(T_{i}-T_{i}\right) V$

Taking the load factor of electric motor, as $0.75,1.5 \mathrm{HP}$ and $3 \mathrm{HP}$ electric motors were selected for the operation of the shelling and separating chamber/press respectively.

\subsection{EVALUATION OF PERFORMANCE ANALYSIS}

The consequence of the effect of moisture content and shelling speed on melon dehusking as well as paddle speed, blow dryer speed and heat on shell/kernel separation were first examined. Thereafter, the extraction efficiency and the milling capacity were determined. The melon seeds used were procured from Omida market in Abeokuta, Ogun state, Nigeria. From the first test, the moisture content and shelling speed at five levels were used. Moisture content determination was carried out using ASAE standard and S.352 (ASAE, 1982). The shelling speed was varied by regulating the gasoline engine speed while different moisture levels were achieved by removing a known quantity of the seeds periodically from a lot that have been soaked in water and dried at varying room temperature. The initial moisture content of the seed was first used at five different inner drum speeds of 850, 950, 1000 and $1200 \mathrm{rpm}$. 


\section{EPRA International Journal of Research and Development (IJRD)

Thereafter, the shelling efficiency, and percentage seed damage, were evaluated using Equations (28) and (29) respectively.

$\mathrm{\eta}_{s}=\left\{\left(m_{s w}+m_{s b}\right) / m_{c} \times 100\right\}$
$\mathrm{\eta}_{b}=\left\{\left(m_{w b}+m_{s b}\right) / m_{c}{ }^{\times} 100\right\}$

Where $m_{s w}, m_{s b}, m_{w b}, m_{c}$ are the masses of seeds shelled (unbroken), unshelled seeds but broken, seeds shelled but broken and seeds put into the machine respectively. Secondly, five different trials were carried out in which the speed of paddle conveyor was operated at 20,24,30,35 and $50 \mathrm{rpm}$ and the blow dryer at the two speed and heat settings of 1000-1200 rpm and 1500-1700W respectively. The paddle conveyor speed was varied by changing the diameter of the driven pulley. In each trial, a known mass of unshelled melon, $m_{u s}$ at the moisture content and shelling speed obtained from the first experiment was introduced into the shelling unit and the time taken to dehull and separate the kernel/shell mix, was noted using a stop watch. Thereafter, the mass of melon kernel/seed received at the chaff outlet, $m_{s}$ as well as the mass of chaff received at the kernel outlet, $t_{s}$ were recorded as per each run and the separation efficiency, $\mathrm{y}_{p}(\%)$ and separation capacity, $S_{c}(\mathrm{~kg} / \mathrm{h})$ defined as the quantity of kernels cleaned per unit time were evaluated using equations (30) and (31) respectively.

$\eta_{p}=\frac{m_{c}}{m_{c}+m_{s}}$

$S_{c}=\frac{m_{c}}{t_{s}}(\mathrm{Kg} / \mathrm{h})$

\subsection{RESULTS AND DISCUSSION}

Results in (Fig. 6 and 7) show that shelling efficiency increased as the moisture level and shelling drum speed increased from $5.2 \%$ to $9.7 \%$ and 850 to $950 \mathrm{rpm}$ respectively but decreased with further increase in both shelling drum speed and moisture level while the percentage seed damage decreased with increase in moisture level but show marked increase with increase in the shelling drum speed. Table 1 also shows the result of shelling test operation.

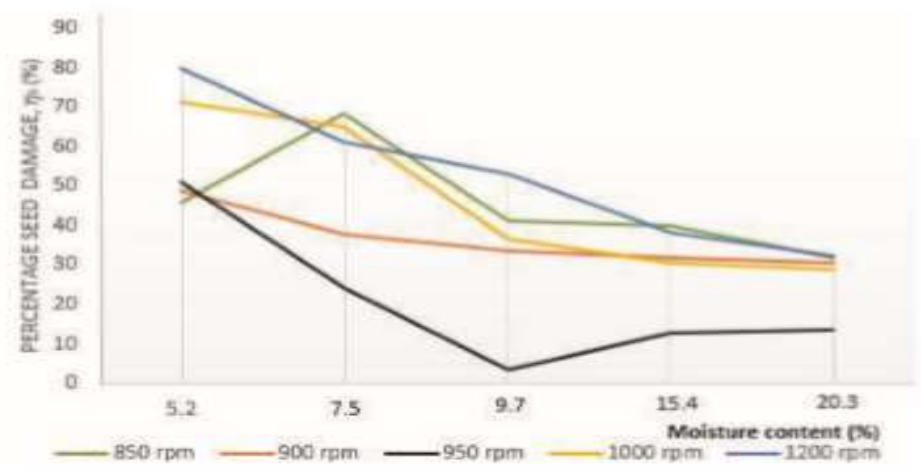

Figure 6. Effect of melon seed moisture content on seed/kernel breakage

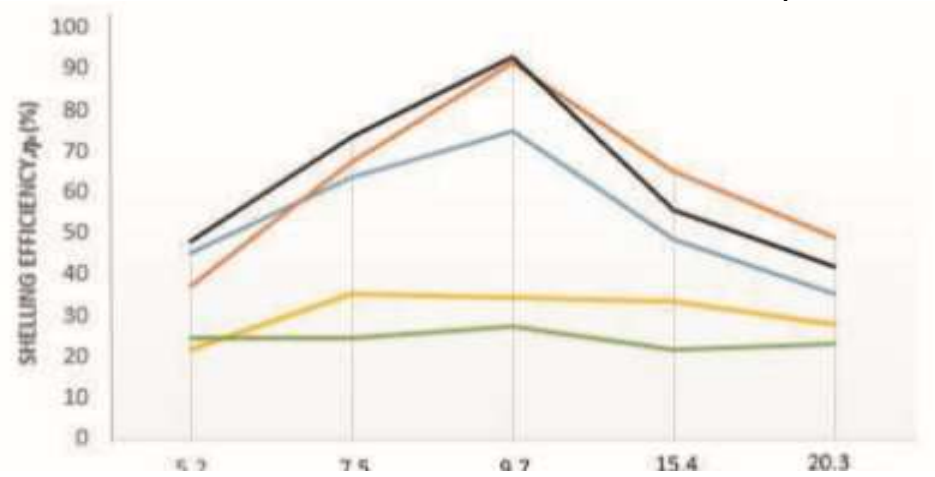

Figure 7.Effect of melon seed moisture content on shelling efficiency. 


\section{EPRA International Journal of Research and Development (IJRD)}

Table 1. Result of Shelling Test Operation

\begin{tabular}{|c|c|c|c|c|c|c|}
\hline S/N & $\begin{array}{c}\text { Weight of } \\
\text { dry seed to } \\
\text { be } \\
\text { shelled(gm) }\end{array}$ & $\begin{array}{c}\text { Weight of } \\
\text { completely } \\
\text { shelled } \\
\text { seed(gm) }\end{array}$ & $\begin{array}{c}\text { Weight of } \\
\text { unshelled } \\
\text { seeds } \\
\text { (gm) }\end{array}$ & $\begin{array}{c}\text { Weight of } \\
\text { partially } \\
\text { shelled and } \\
\text { broken } \\
\text { seed(gm) }\end{array}$ & $\begin{array}{c}\text { Weight of } \\
\text { crushed } \\
\text { seeds (gm) }\end{array}$ & $\begin{array}{c}\text { Efficiency } \\
\text { (\%) }\end{array}$ \\
\hline 1 & 70 & 60.9 & 5.6 & 3.0 & 0.5 & 87.0 \\
\hline 2 & 140 & 131.6 & 5.0 & 3.0 & 0.4 & 92.0 \\
\hline 3 & 210 & 203.0 & 4.0 & 2.7 & 0.3 & 93.7 \\
\hline 4 & 280 & 273.7 & 4.0 & 2.0 & 0.3 & 97.5 \\
\hline 5 & 350 & 344.4 & 3.5 & 1.8 & 0.3 & 94.4 \\
\hline
\end{tabular}

Average percentage performance $=(87.0+92.0+93.7+97.5+94.4) / 5=92.92 \%$

This totally confirmed that the efficiency of this improved continuous shelling and cleaning machine is very good.

\subsection{CONCLUSION}

This melon shelling and cleaning machine was made from locally available materials, the gasoline powered melon seed sheller was designed constructed and evaluated in this study. Results obtained showed that the machine can effectively shell melon seeds and that seed moisture contents and the speed of the shelling machine affected the performance indicators. The shelling efficiency increases with an increase in moisture content and decrease in shelling speed, it can be conveniently operated with little or no technical skill. Individuals can acquire it for domestic use and melon local farmers as well as medium scale industries involved in melon shelling can also make use of the machine since it does not require high skill labour. The average percentage performance of the melon shelling machine was found to be $92.92 \%$. The average percentage of unshelled melon seeds plus crushed melon seeds was $5.22 \%$. The production cost was minimal which is cheap compared to the cost of the imported ones available in the market.

\section{SOURCES OF FUNDING}

This research is fully funded by Tertiary Education Trust Fund grant (Tetfund 2016).

\section{CONFLICT OF INTEREST}

The author has declared that no competing interests exist.

\section{ACKNOWLEDGMENT}

None.

\section{REFERENCES}

1. Samaila R.S. and Chukwu O. (2014). Development of a Motorised Egusi Melon Seeds Oil Expeller. Journal of Agricultural Engineering and Technology (JAET), Volume 22, No. 2, pp. 13-25

2. Tuhin Das. (2015). http://www. Onlyfoods.net/egusi.html. Assessed 25/9/2015.

3. Nwakire JN, Ugwuishiwu BO, Ohagwu CJ (2011) Design, construction and performance analysis of a maize thresher for rural dweller. Nigerian Journal of Technology 30: 49-51.

4. Prahan RC, Naik SN, Bhatnagar N, Vijay VK (2010) Design, development and testing of hand-operated decorticator for Jatropha fruit. Applied Energy 87: 762-768.

5. Adekunle AS, Ohijeagbon IO, Olusegun HD (2009) Development and performance evaluation of manually and motorized operated melon shelling machine using impact technique. Journal of Engineering Science and Technology Review 2: 12-1.

6. Odigboh EU (1979) Impact egusi shelling machine. Transaction of the ASAE 22: 1264-1269.

7. Sobowale SS, Adebiyi JA, Adebo OA (2015) Design, Construction and Performance Evaluation of a Melon Seeds Sheller. J Food Process Technol 6: 463. doi:10.4172/2157-7110.1000463. 


\section{SJIF Impact Factor: 7.001| ISI I.F.Value:1.241| Journal DOI: 10.36713/epra2016 \\ ISSN: 2455-7838(Online) \\ EPRA International Journal of Research and Development (IJRD) \\ Volume: 5 | Issue: 11 | November 2020 \\ - Peer Reviewed Journal}

8. James KM, Umogbai V, Itodo IN (2011) Development and evaluation of a melon shelling and cleaning machine. Journal of Emerging Trends in Engineering and Applied Sciences 2: 383-388.

9. Nwakire JN, Ugwuishiwu BO, Ohagwu CJ (2011) Design, construction and performance analysis of a maize thresher for rural dweller. Nigerian Journal of Technology 30: 49-51.

10. Shittu SK, Ndrika VIO (2012) Development and performance tests of a melon (egusi) seed shelling machine. Agricultural Engineering International 14: 1-11.

11. Kassim M.J., Victor U. and Isaac I. (2011). Development and Evaluation of a Melon Shelling and Cleaning Machine. Journal of Emerging Trends in Engineering and Applied Sciences, (JETEAS), Vol. 2 (3), pp.383-388.

12. Samaila R.S. and Chukwu O. (2014). Development of a Motorised Egusi Melon Seeds Oil Expeller. Journal of Agricultural Engineering and Technology (JAET), Volume 22, No. 2, pp. 13-25.

13. Tuhin Das. (2015). http://www.Onlyfoods.net/egusi.html. Assessed 25/9/2015.

14. Oriaku E.C., Agulanna C.N., and Nwannewuihe H.U. (2013). Comparative Performance Analysis of Melon (Colocynthis Citrullus L.) De-Husking and Separation Machines by Principles of Impact and Attrition. International Journal of Multidisciplinary Sciences and Engineering, Vol. 4, No. 7, Pp.53-59.

15. Fashina $A B$ (1971) The design and development of a melon sheller. University of Ife, Nigeria.

16. Odigboh EU (1979) Impact egusi shelling machine. Transaction of the ASAE 22: 1264-1269.

17. Fadamoro I (1999) Design and Construction of a manually operated melon sheller. University of Ilorin, Nigeria.

18. Fashina $A B$ (1971) The design and development of a melon sheller. University of Ife, Nigeria.

19. Khurmi, RS, Gupta JK (2004) Theory of Machines, Eurasia Publishing House, New Delhi, India.

20. Oja, P : Constructuion of melon shelling machine, Unpublished B.Sc. Report. Dept. of Agricultural Engineering, University of Ilorin, Nigeria, 1991.

21. Akintunde, B.O., Oyawale, F.A., Tunde-Akintunde, T.Y: Design and fabrication of a cassava peeling machine. Nigerian Food Journal Vol. 23 pg. 231-238. 2005.

22. Fadamoro I (1999) Design and Construction of a manually operated melon sheller. University of Ilorin, Nigeria. 